\title{
Ethanol Concentration Effect of Mangoesten Pell Extract to Total Phenol Content
}

\author{
${ }^{1}$ Mustofa Ahda \\ ${ }^{1}$ Fakultas Farmasi Universitas Ahmad Dahlan \\ Jln. Prof. Dr. Supomo Yogyakarta, Telp. (0274) 379418 \\ Mustofa_ahda@yahoo.com
}

\begin{abstract}
ABSTRAK
Telah penelitian tentang pengaruh konsentrasi etanol terhadap kandungan fenol total pada kulit manggis. Penelitian ini bertujuan sebagai effisiensi penggunaan pelarut yang digunakan dalam proses ekstraksi. Proses ekstraksi yang digunakan dalam penelitian ini menggunakan teknik maserasi.

Penelitian ini dengan melakukan variasi konsentrasi etanol 100\%, 80\%, 50\%, 20\%, 0\% sebagai pelarut yang digunakan dalam proses maserasi selama 24 jam disertai dengan pengadukan. Kemudian hasil ekstrak cair dievaporasi sampai mendapat ekstraks kental, dan selanjutnya ekstraks kental diuapkan sampai memperoleh ekstraks kering masing-masing pelarut tersebut.

Hasil penelitian menunjukkan bahwa konsentrasi etanol 100\% mampu melakukan proses ekstraksi yang optimal dengan kandungan total fenol sebesar $35,21 \% \mathrm{~b} / \mathrm{b}$ yang equivalen terhadap asam galat.
\end{abstract}

Kata Kunci : Fenol total, Ekstraksi, Maserasi, Ekstrak, Asam Galat

\section{ABSTRACT}

The research of ethanol concentration effect on phenol total content from mangoesten peel has been done. This study look for the efficiency of solvents in the extraction process. The extraction process used in this study using the technique of maceration.

This study carried out with different ethanol concentration such as $100 \%, 80 \%, 50 \%, 20 \%, 0 \%$ used in the process of maceration for 24 hours by stirring continuely. Then the liquid extract ethanol is evaporated until get sthick extracts, and subsequently sthick extracts were evaporated to obtain dry extracts.

The results showed that the ethanol concentration is $100 \%$ capable of performing optimal extraction process with total phenol content of $35.21 \% \mathrm{w} / \mathrm{w}$ which is equivalent to gallic acid.

Keywords: Total phenol, Extraction, Maceration, Extract, Gallic acid

\section{Pendahuluan}

Antioksidan merupakan suatu senyawa yang mampu mencegah terjadinya reaksi oksidasi yang disebabkan oleh radikal bebas. Kemampuan antioksidan ini dikarenakan senyawa antioksidan memiliki ciri khas yaitu memiliki gugus fenolik. Hasil pengujian epidemiologi menunjukkan bahwa mengkonsumsi buah-buahan dan sayursayuran yang banyak mengandung senyawa fenol dapat menurunkan resiko terkena penyakit jantung dan kanker karena senyawa fenolik yang banyak terdapat dalam 
tumbuhan dapat berfungsi sebagai mangostin, garcinon B, mangostanol, selain antioksidan (Sandrasari, 2009).

Penelitian ini akan menguji kandungan senyawa fenol yang terdapat dalam kulit manggis manggis. Tumbuhan manggis ini merupakan tumbuhan yang dapat tumbuh di daerah tropis seperti Indonesia. Manggis memiliki nama latin Garcinia mangostana L. termasuk dalam famili Guttiferae dan merupakan species terbaik dari genus Garcia (Qosim, 2007). Manggis memiliki banyak manfaat karena banyaknya senyawa aktif yang dapat berfungsi sebagai antioksidan. Oleh karena itu, di luar negeri buah manggis dikenal sebagai buah yang memiliki kadar antioksidan tertinggi di dunia (Miryanti, dkk., 2012).

Selain buahnya kandungan senyawa aktifnya juga terdapat pada bagian kulitnya. Beberapa senyawa aktif yang terdapat dalam kulit manggis berupa Xanthone, anthosianin dan beberapa senyawa lainnya. Xantone merupakan senyawa yang tidak ditemui pada buah-buahan lainnya kecuali pada manggis, karena itu manggis di dunia diberikan julukan "Queen of Fruit" atau si ratu buah (Iswari dan Sudaryono, 2007). Derivatif senyawa Xanthone seperti mangostin, Sedangkan menurut Purwaningsih dan Ersam mangostenol A, mangostinon A, (2007), kemampuan turunan xanthone mangostinon B, trapezifolixanthone, sederhana juga memiliki aktifitas antioksidan tovophyllin B, alfa mangostin, beta yang tinggi terhadap radikal bebas DPPH. 
Banyaknya kandungan aktif dalam kulit manggis diharapkan juga kandungan senyawa fenoliknya tinggi. Oleh karena itu, pemanfaatan kulit manggis sebagai sumber antioksidan ini maka perlu dilakukan penentuan kandungan total fenolnya. Selain itu, penelitian ini juga bertujuan untuk menentukan konsentrasi optimum yang dapat menghasilkan kandungan fenol total terekstrak. Penggunaan konsentrasi etanol yang tinggi menghasilkan kadar xanthone dan anthosianin yang besar akan tetapi kadar taninnya menurun (Pebriyanthi, 2010). Oleh karena itu, maka perlu dilakukan variasi konsentrasi etanol sebagai pengekstraknya. Hal ini dimaksudkan agar proses penggunaan etanol sebagai pengektraks lebih efisien dan ekonomis.

\section{Tujuan Penelitian}

Penelitian tentang mempelajari pengaruh konsentrasi ini bertujuan untuk:

1. Mempelajari pengaruh penggunaan variasi konsentrasi pengekstrak dalam menghasilkan senyawa aktif dari kulit manggis

2. Memberikan informasi tentang konsentrasi etanol yang mampu mengekstrak optimal pada senyawa aktif manggis.

\section{Metode Penelitian}

\section{Bahan}

Bahan baku yang digunakan adalah kulit buah manggis dari pasar buah yogyakarta. Bahan baku pembantu yang digunakan antara lain pelarut etanol sebagai pengekstrak. Bahan kimia lainnya adalah aquadest, $\mathrm{NaOH}$, Reagen Folin Ceilteau, $\mathrm{FeCl}_{3}$.

\section{Alat}

Alat-alat yang digunakan dalam penelitian ini adalah beaker glass, labu takar, erlenmeyer, corong, kertas saring, timbangan analitik, rotary evaporator vakum, spektrofotometer UV-Vis 1700.

\section{Prosedur Penelitian}

\section{a. Persiapan Sampel}

Buah manggis dikupas dan dipisahkan antara isi dan kulitnya. Kulit buah manggis dikeringkan pada udara terbuka selama 7 hari, kemudian digiling menjadi bubuk menggunakan mesin penggiling.

\section{b. Pembuatan Ekstrak}

Bubuk halus ditimbang 100 gram dan dimaserasi dengan $400 \mathrm{ml}$ etanol absolut selama 24 jam dengan pengadukan. Perlakuan yang sama terhadap variasi konsentrasi etanol $80 \%, 50 \%, 20 \%$ dan $0 \%$. 
Setelah perlakuan maserasi selama 24 jam larutan disaring dengan menggunakan vakum dan kertas saring untuk memisahkan ampas dan filtratnya, filtrat kemudian dievaporasi dengan rotary evaporator vakum untuk menguapkan pelarutnya, sehingga diperoleh ekstrak kental dari kulit buah manggis dan kemudian dikeringkan agar diperoleh ekstrak kering.

\section{c. Identifikasi Kandungan Fenol Total}

Penentuan fenol total dengan metode pengujian menggunakan folin Ciocalteau. Dibuat konsentrasi standar asam galat (15, 20, 25, 30, 40, 50 dan $60 \mu \mathrm{g} / \mathrm{ml})$. Kemudian larutan standar asam galat diambil $0,3 \mathrm{~mL}$ ditambahkan 1,5 $\mathrm{mL}$ reagen fenol yaitu folin Ciocalteu (1:10) diaduk sampai homogen. Setelah 5 menit, ditambahkan 1,2 mL sodium karbonat dan diamkan selama 60 menit. Kemudian dilakukan pengukuran absorbansi pada panjang gelombang 748,6 $\mathrm{nm}$ menggunakan spektroskopi UV-Vis. Sebanyak 100,0 mg ekstrak etanol kulit manggis dilarutkan sampai volume $25,0 \mathrm{ml}$ dilakukan sama dengan perlakuan standar kemudian dianalisis dengan spektroskopi $\mathrm{UV}-\mathrm{Vis}$.

\section{Pembahasan}

Penentuan kandungan total fenol dalam suatu sedian ekstraks bahan alam sangat penting diketahui karena aktifitas suatu bahan alam dapat digunakan sebagai antioksidan salah satunya tergantung kandungan total fenol dalam bahan alam tersebut. Proses kandungan fenol yang terekstrak dari bahan alam juga sangat dipengaruhi oleh sifat bahan pengekstrak tersebut. Oleh karena itu, penelitian ini menfokuskan pada pengaruh konsentrasi etanol sebagai bahan pengekstrak pada kulit manggis.

\section{Analisis kualitatif kandungan fenol}

Analisis kualitatif pada ekstrak etanol kulit manggis dilakukan sebagai langkah untuk mendeteksi adanya senyawa fenolik dalam ekstrak etanol kulit manggis. Hasil analisis kualitatif ekstrak kulit manggis seperti gambar 1. 


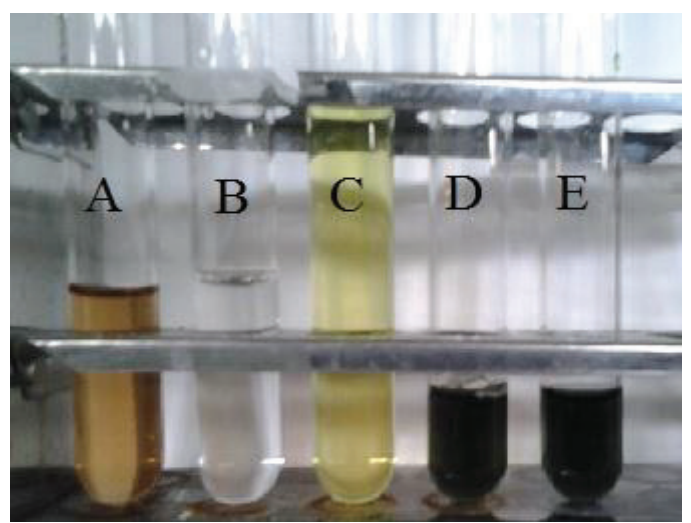

Gambar 1. Hasil warna senyawa A) Ekstrak kulit manggis 100\%, B) Asam galat, C) Folin cielteau, D) Ekstraks kulit manggis + Folin cielteau, E) Asam galat + Folin cielteau

Hasil analisis kualitatif dengan reagen Kondisi reaksi ini harus dalam keadaan folin cielteau menghasilkan terbentuknya basa karena senyawa fenolik dalam bentuk warna biru. Hal ini dikarenakan senyawa ion fenolat yang akan mudah terjadi oksidasi fenolik dalam ekstrak mampu mereduksi sehingga pembentukan kompleks reagen folin dalam keadaan basa sehingga molybdenum. Proses pembentukan ion membentuk kompleks molybdenum biru fenolat seperti Gambar 2. (fosfotungstat-fosfomolibdat).

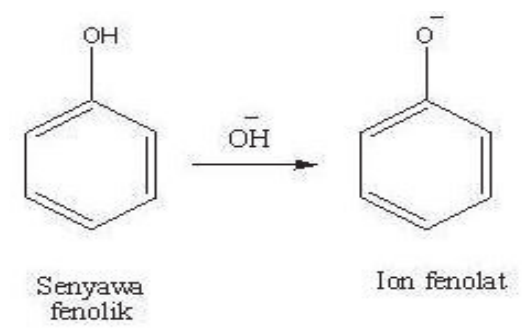

Gambar 2. Pembentukan ion enolat pada kondisi basa

Hasil analisis kualitatif menggunakan reaksi kimia menunjukkan adanya kandungan fenolik dalam ekstrak kulit manggis.

\section{Analisis kualitatif kandungan fenol total}

Penentuan kualitatif tersebut mengindikasikan adanya reduktor yang mampu mereduksi senyawa folin dan menyebabkan terjadinya kompleks fosfotungstat-fosfomolibdat yang berwarna 
biru. Senyawa reduktor yang terindikasi yang sering digunakan ialah metode kurva dalam suatu ekstrak biasanya dalam bentuk baku. Hal ini karena pada pembuatan kurva senyawa fenolik. Oleh karena itu, maka baku berarti kita telah menentukan daerah penelitian ini dilanjutkan terhadap kandungan kerja dalam menentukan kadar suatu sampel. fenol total yang terdapat dalam ekstrak Hal yang perlu diperhatikan dalam dengan variasi konsentrasi etanol sebagai pembuatan kurva baku ialah harga pengekstrak. linearitasnya. Proses pembuatan kurva baku dilakukan dengan waktu operasi selama 60 Pembuatan kurva kalibrasi asam galat menit dan pada panjang gelombang $748,6 \mathrm{~nm}$ Metode penentuan kadar dalam suatu (Gambar 3). sampel ada berbagai cara. Salah satu metode

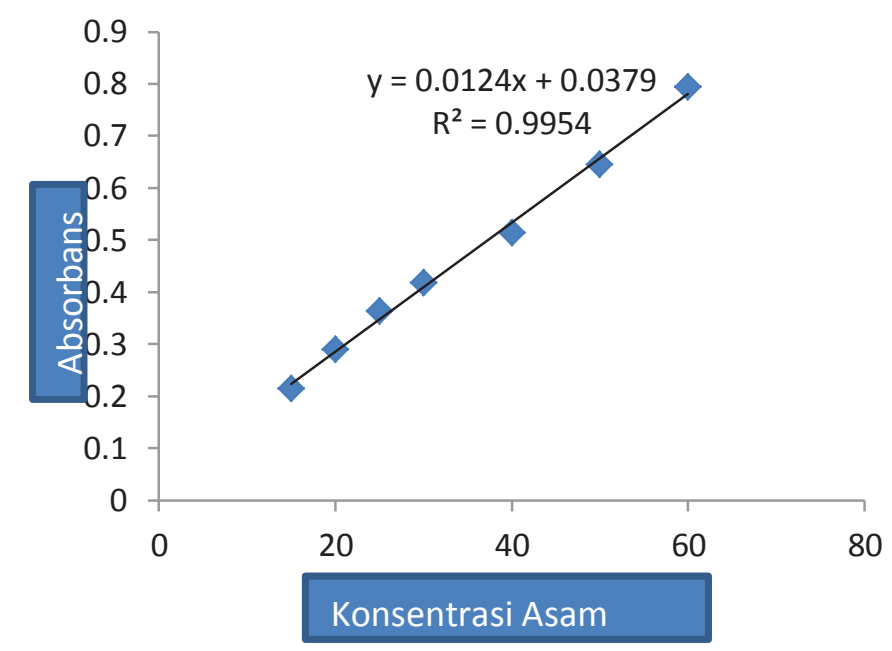

Gambar 3. Hasil kurva baku asam galat pada lambda maks $748,4 \mathrm{~nm}$

\begin{abstract}
Kandungan fenol total dalam ekstrak tinggi mampu menghasilkan kandungan total etanol kulit manggis fenol yang tinggi sedangkan kandungan total

Hasil kandungan total yang terdapat fenol yang diekstrak dengan air (tanpa dalam ekstrak manggis sangat dipengaruhi metanol) hasilnya menunjukkan kadar yang oleh pelarut yang digunakan. Hasil penelitian rendah (Gambar 4).
\end{abstract} menunjukkan bahwa konsentrasi etanol yang 


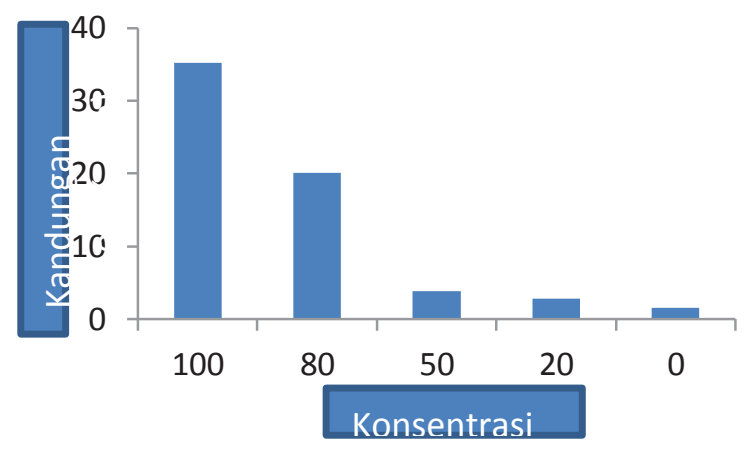

Gambar 4. Hasil kandungan total fenol pada variasi konsentrasi etanol sebagai pengekstrak

Gambar 4. Menunjukkan adanya pengaruh yang signifikan penggunaan pelarut dalam proses ekstraksi pada kulit manggis terhadap kandungan fenol total yang terekstrak. Konsentrasi etanol $100 \%$ mampu mengekstrak senyawa fenolik sebesar 35,21 $\% \mathrm{~b} / \mathrm{b}$ yang equivalen terhadap asam galat. de Oliveira, dkk., (2012) menyimpulkan bahwa pada famili Malvaceae yang memiliki kandungan total fenol yang tinggi dan juga aktifitas oksidan yang bagus tetapi perlu dilakukan studi identifikasi senyawa fenolik yang memiliki kemampuan aktifitas antioksidan. Oleh karena itu, kandungan senyawa fenolik sebesar 35,21\% pada kulit manggis perlu dilakukan identifikasi jenis senyawa fenolik yang terdapat pada ekstrak etanol kulit manggis dengan konsentrasi etanol $100 \%$.

\section{Kesimpulan}

a. Variasi konsentrasi etanol dalam proses maserasi mampu menghasilkan kandungan total fenol terekstraks pada kulit manggis berbeda-beda.

b. Konsentrasi etanol $100 \%$ mampu menghasilkan kandungan total fenol tertinggi dengan konsentasi total fenol (b/b) sebesar 35, $21 \%$ yang equivalen terhadap asam galat.

\section{Ucapan Terimakasih}

Kami mengucapkan terima kasih kepada Lembaga Pengembangan Penelitian UAD (LPP UAD) yang telah membiayai penelitian ini melalui hibah program dosen pemula (PDP) pada tahun 2014.

\section{Pustaka}

Adriana Maria Fernandes de Oliveira, A.M.F., Pinheiro, L.S., Pereira, C.K.S, Matias, W.N., Gomes, R.A., 
Chaves, O.S., de Souza, M.F.V., de Almeida, R.N., dan de Assis, T.S., 2012, Total Phenolic Content and Antioxidant Activity of Some Malvaceae Family Species, Antioxidants, 1, 33-43.

Chaverri, J.P., Rodríguez, N.C., Ibarra, M.O., Rojas, J.M.P., 2008, Medicinal properties of mangosteen (Garcinia mangostana), Food and Chemical Toxicology, 6, 3227-3239.

Ditjen POM, 1986, Sediaan Galenik, Departemen Kesehatan Republik Indonesia, Jakarta.

Harwood, L.M., dan Moody, C.J., 1989, Experimental Organic Chemistry, Principles and Practice, Blackwel Scientific Publication, Oxford, London.

Ho, C. K., Huang, Chen, 2002, Garcinone E, a Xanthone Derivative, Has Potent Cytotoxic Effect Against Hepatocellular Carcinoma Cell Lines, Planta Med, 68, 975-979.

Houghton, P.J., dan Rahman, A., 1998, Laboratory Handbook for the Fractination of Natural Extracts, Pebriyanthi., N.E., 2010, Ekstraksi Xanthone Chapman and Hall, London.
Ilnuma, M., Tosa, H., Tanaka, T., Asai, F., Kobayashi, Y., Shimano, R., and Miauchi, K.I, 1996, Antibacterial Activity of Xanthones from Guittiferaeous Plants againt Methicillin-resistant Staphylococcus aureus, J. Pharm. Pharmacol, 48, 861-865.

Iswari, K., dan Sudaryono, T., 2007, BPTP SUMBAR 4 Jenis Olahan Manggis, Si Ratu Buah Dunia dari Sumbar, Tabloid Sinar Tani.

Ketaren, S., 1986, Pengantar Teknologi Minyak dan Lemak Pangan, UI Press, Jakarta.

Khan, A., Rahman, M., Islam, M.S., 2010, Isolation and Bioactivity of a Xanthone Glycoside from Peperomia pellucid, Life Sciences and Medicine Research, LSMR-1.

Miryanti, A., Lanny, S., Kurniawan, B., dan Stephen, I., 2012, Ekstraksi Antioksidan Dari Kulit Buah Manggis (Garcinia mangostana L.), Universitas Katolik Parahyangan, Bandung.

Dari Kulit Buah Manggis (Garcinia mangostana L.) dan Aplikasinya Dalam Bentuk Sirup, Skripsi, IPB. 
Purwaningsih, Y., dan Ersam, T., 2007, Tjahjani, S., dan Widowati, W., 2013, Senyawa Santon Sebagai Antioksi Potensi Beberapa Senyawa Xanthone dan dari Kayu Batang Garcinia sebagai Antioksidan dan Anti-malaria tetranda Pierre, Akta Kimindo, 2, 2, serta Sinergisme dengan Artemisinin $103-108$. in Vitro, J Indon Med Assoc., 63, 3.

Qosim, W.A., 2007, Kulit Buah Manggis Sebagai Antioksidan. Available at http:www.pikiranrakyat.com/cetak/2007/022007/15/ka mpus/lain01.htm.

Sandrasari, D.A., 2009, Kapasitas Antioksidan dan Hubungannya Dengan Nilai Total Fenol Ekstrak Sayuran Indigenous, thesis, IPB.

Shahidi, F., 1997, Natural Antioxidants (Chemistry, Health Effect, and Applications), AOAC Press, Champaign, Illinois.

Supiyanti, W., Wulansari, E.D., dan Kusmita, L., 2010, Uji Aktifitas Antioksidan Dan Penentuan Kandungan Antosianin Total Kulit Buah Manggis (Garcinia mangostana L), Majalah Obat Tradisional, 15(2), $64-70$.

Teixeira, M., Afonso, C.M.M. Pinto, M.M.M.M. and Barbosa, C.M. 2003, A Validated HPLC Method for the Assay of Xanthoneand 3Methoxyxanthone in PLGA Nanocapsules, JCS, 41, 371-376. 